\title{
Localization of L-Type $\mathrm{Ca}^{2+}$ Channels at Perisynaptic Glial Cells of the Frog Neuromuscular Junction
}

\author{
Richard Robitaille, ${ }^{1}$ Marie-Josée Bourque, ${ }^{1}$ and Sylvie Vandaele ${ }^{2}$ \\ ${ }^{1}$ Centre de Recherche en Sciences Neurologiques, Département de Physiologie, Université de Montréal, \\ Montréal H3C 3J7, Canada, and 2Département de Pathologie, Université de Montréal, Montréal H3C 3J7, Canada
}

The presence of L-type $\mathrm{Ca}^{2+}$ channels at the frog neuromuscular junction (nmj) was studied by monitoring changes in intracellular $\mathrm{Ca}^{2+}$ evoked in presynaptic terminals and perisynaptic Schwann cells (PSCs) and by studying the distribution of $\mathrm{Ca}^{2+}$ channels using a monoclonal antibody directed against the $\alpha 2 / \delta$ subunit of $L$ channels. L-type $\mathrm{Ca}^{2+}$ channel agonist and antagonist had no effect on resting level of fluorescence and nerve-evoked $\mathrm{Ca}^{2+}$ responses in presynaptic terminals. However, depolarization of PSCs induced by $\mathrm{KCl}(25 \mathrm{~mm})$ produced entry of $\mathrm{Ca}^{2+}$, which was prevented by L-type $\mathrm{Ca}^{2+}$ channel blockers, (+)R Bay K 8644 or nimodipine. Labeling of $\mathrm{Ca}^{2+}$ channels revealed an intracellular epitope with an irregular and spotty distribution along the endplate. Similar results were obtained with a fluorescent phenylalkylamine [(-)DMBODIPY-PAA], a blocker of L-type $\mathrm{Ca}^{2+}$ channels. $\mathrm{Ca}^{2+}$ chan- nel labeling remained in absence of nerve terminals but was absent after mechanical removal of nerve terminals and PSCs. Most $\mathrm{Ca}^{2+}$ channel spots were distributed in between bands of cholinergic receptors labeled with $\alpha$-bungarotoxin-TRITC. Cross sections of motor endplates revealed that labeling of $\mathrm{Ca}^{2+}$ channels was found only at the level of the synaptic cleft and not all around the PSCs. We conclude that L-type $\mathrm{Ca}^{2+}$ channels are located in perisynaptic glial cells in an appropriate location to sense depolarization induced by neurotransmitters and thus may support possible roles of glial cells on synaptic function.

Key words: L-type $\mathrm{Ca}^{2+}$ channels; phenylalkylamine; dihydropyridines; active zone; perisynaptic Schwann cell; $\mathrm{Ca}^{2+}$; glial cells; $\omega$-conotoxin GVIA; transmitter release
Ncurotransmitter relcase at chemical synapses is triggered by a transient entry of $\mathrm{Ca}^{2+}$ through $\mathrm{Ca}^{2+}$ channels (Augustine et al., 1987). At frog and mouse neuromuscular junctions (nmj), $\mathrm{Ca}^{2+}$ channels involved in transmitter release are thought to be of the $\mathrm{N}$ and $\mathrm{P}$ types, respectively. At frog $\mathrm{nmj}$, transmitter release and nerve-evoked $\mathrm{Ca}^{2+}$ entry in presynaptic terminals were blocked by the $\mathrm{N}$-type $\mathrm{Ca}^{2+}$ channel blocker $\omega$-conotoxin GVIA ( $\omega$-CgTx) (Kerr and Yoshikami, 1984; Robitaille et al., 1990, 1993a), and $\mathrm{Ca}^{2+}$ channels were labeled with fluorescent $\omega$-CgTx (Robitaille et al., 1990, 1993a,b; Cohen et al., 1991). Similar results were obtained at the mouse nmj using P-type $\mathrm{Ca}^{2+}$ channel blockers such as the funnel web spider toxin or $\omega$-agatoxin-IVA-related peptides (Llinàs et al., 1992; Uchitel et al., 1992; Wray and Porter, 1993; Bowersox et al., 1995; Sugiura et al., 1995). Despite these observations, there are still uncertainties regarding the possibility that other types of $\mathrm{Ca}^{2+}$ channels also are present at these nmj. Indecd, a number of reports indicated that synaptic transmission at these two synapses also was modulated by L-type $\mathrm{Ca}^{2+}$ channel

Received July 6, 1995; revised Sept. 8, 1995; accepted Sept. 13, 1995.

This work was supported by Grants MT-12057 from the Medical Research Council and 930093-103 from the Fonds de la Recherche en Santé du Québec (R.R.), Grant 95ER2119 from FCAR, and grants from Université de Montréal. S.V. was supported by grants from The Savoy Foundation for Epilepsy and grants from the Université de Montréal. R.R. was a scholar of the Medical Research Council of Canada and an Alfred P. Sloan Research Fellow. M.J.B. was supported by a studentship from Groupe de Recherche sur le Système Nerveux Central (FCAR). We thank Vincent Castellucci, Milton P. Charlton, and John Georgiou for helpful suggestions and critical reading of the manuscript, Dr. M. Bendayan, Département d'Anatomie, Université de Montréal for the use of the BioRad 600 confocal microscope, and Mrs. D. Cyr and G. Filosofi for their help in the preparation of the figures.

Correspondence should be addressed to Richard Robitaille, Départément de Physiologie, Université de Montréal, P.O. Box 6128, Station "Centre-Ville," Montréal H3C 3J7, Canada.

Copyright $\mathbb{C} 1995$ Society for Neuroscience $0270-6474 / 95 / 160148-11 \$ 05.00 / 0$ agonist and antagonist (Publicover and Duncan, 1979; Atchison and O'Leary, 1987; Pancrazio et al., 1989; Ribera and Nastuk, 1989; Kawagoe et al., 1990).

In the present study, we explored the possibility that L-type $\mathrm{Ca}^{2+}$ channels are present at the frog nmj and, in particular, that these channels are located in the perisynaptic Schwann cells (PSCs), glial cells at this synapse. Glial cells are appealing candidates because they are closely associated with synapses, possess L-type $\mathrm{Ca}^{2}$ channels as well as a large variety of other ion channels (Barres et al., 1990; Ritchie, 1992), are receptors for most neurotransmitters and, most importantly, react to neurotransmitters released during nerveevoked synaptic transmission (Dani et al., 1992; Chiu and Kriegler, 1994; Parpura et al., 1994). At the frog nmj, PSCs send processes in between the nerve terminal and the muscle fiber at irregular intervals between the release sites (Fig. 1) (Birks et al., 1960; Dreyer et al., 1973; Couteaux and Pécot-Dechavassine, 1974; Peper et al., 1974). As with other glial cells, PSCs react to transmitter release during synaptic transmission and possess a variety of receptors (Jahromi et al., 1992, 1993; Reist and Smith, 1992; Georgiou et al., 1994; Robitaille, 1995).

The presence of $\mathrm{Ca}^{2+}$ channels at PSCs of the frog nmj was revealed by the induction of depolarization-induced $\mathrm{Ca}^{2+}$ entry, which was not blocked by $\omega$-CgTx (Jahromi et al., 1992) but was modulated by an ATP receptor $\left(\mathrm{P}_{2 \mathrm{x}}\right.$ type) (Robitaille, 1995). In the present study, two approaches were used to test for the presence of L-type $\mathrm{Ca}^{2+}$ channels at the frog nmj. First, we examined the ability of $\mathrm{L}$ - and $\mathrm{N}$-type $\mathrm{Ca}^{2+}$ channel agonist and antagonist to affect $\mathrm{Ca}^{2+}$ entry in nerve terminals and PSCs. Second, L-type $\mathrm{Ca}^{2+}$ channel distribution was examined using a monoclonal antibody raised against L-type $\mathrm{Ca}^{2+}$ channels (Vandaele et al., 1987). 


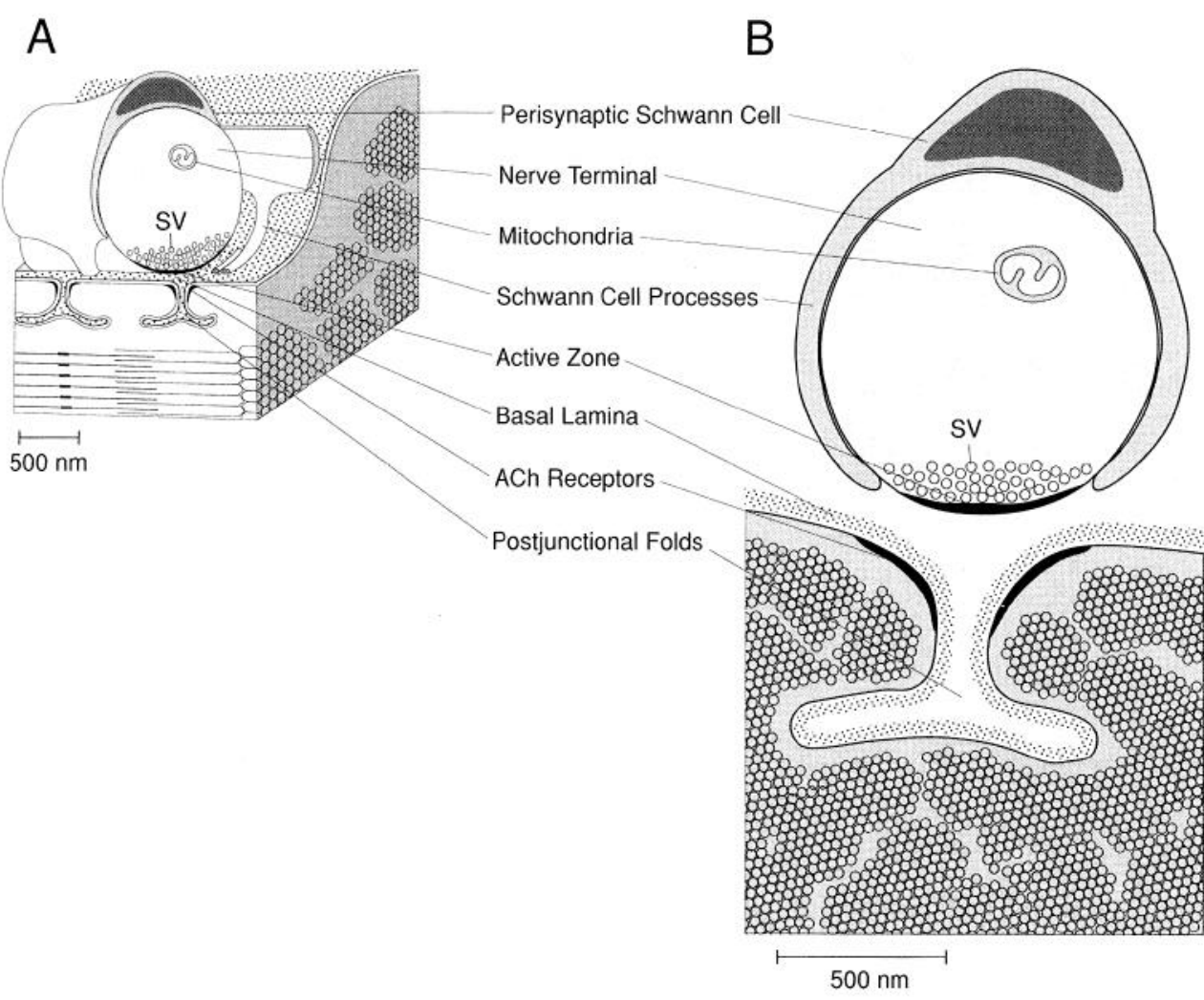

Figure 1. Anatomical relationship between perisynaptic Schwann cells and presynaptic nerve terminal. $A$, Diagram of the frog $\mathrm{nmj}$ illustrating the position of the PSCs in relation to transmitter release sites of the nerve terminal. The PSC covers the nerve terminal and sends processes in between the nerve terminal and the muscle fiber. Transmitter release sites or active zones are located at regular intervals of $1 \mu \mathrm{m}$, opposite clusters of cholinergic receptors. The processes of PSCs are located at irregular intervals between active zones. $B$, Diagram of a cross section of frog endplate illustrating the close proximity of Schwann cell processes with active zones. The processes can be as close as a few tens of nanometers. $S V$, synaptic vesicle.

\section{MATERIALS AND METHODS}

Experiments were performed on nmj of cutaneous pectoris muscles of Rana pipiens frogs. Frog Ringer's solution contained (in $\mathrm{mM}$ ): $120 \mathrm{NaCl}$, $2 \mathrm{KCl}, 1 \mathrm{NaHCO}_{3}, 1.8 \mathrm{CaCl}_{2}$, and $5 \mathrm{HEPES} / \mathrm{NaOH}, \mathrm{pH} 7.2$.

Calcium imaging of PSCs. Nerve-muscle preparations were removed from the frogs and pinned down in a recording chamber coated with Sylgard. The membrane permeant form of the $\mathrm{Ca}^{2+}$ indicator fluo 3 (fluo 3-AM, Molecular Probes, Eugene, OR) was used for imaging $\mathrm{Ca}^{2+}$ changes in PSCs (Kao et al., 1989; Jahromi et al., 1992; Georgiou et al., 1994; Robitaille, 1995). Preparations were incubated with a solution containing $10 \mu \mathrm{M}$ fluo 3 -AM with a final concentration of $1 \%$ dimethyl sulfoxide and $0.02 \%$ pluronic acid for $120-150 \mathrm{~min}$ at $21-23^{\circ} \mathrm{C}$. Partial chelation of heavy metal ions was achieved with tetrakis (2-pyridylmethyl) ethylenediamine (20 $\mu \mathrm{M}$; Molecular Probes) (Arslan et al., 1985; Jahromi et al., 1992).

Changes in fluorescence intensity were detected with an intensified CCD camera system (Sony camera XC-77 and a Hamamatsu intensifier, C-2487, Hamamatsu City, Japan), and images were digitized by a computer using the Image1 software (Universal Imaging, West Chester, PA). Additional magnification was obtained with an optizoom (Nikon, Missisauga, Canada). The excitation wavelength was $485 \pm 20 \mathrm{~nm}$, and the emitted light was detected through a low pass filter with cutoff at $515 \mathrm{~nm}$. Neutral density filters of at least $50 \%$ were used to minimize damage to the preparations caused by an excess of light energy. Some experiments were performed using a BioRad 600 laser scanning confocal microscope equipped with an argon ion laser (Hertfordshire, UK). The $488 \mathrm{~nm}$ line of the laser was attenuated to $1 \%$, and the emitted fluorescent signals were detected through a low pass filter with cutoff wavelength at $515 \mathrm{~nm}$. A $40 \times$ water immersion lens was used (Nikon, 0.55 NA or Olympus, 0.75 NA, Tokyo, Japan). Surface nmj were located using transmitted light microscopy, which allows a reliable identification of PSCs (Georgiou et al., 1994). The fluorescence intensity $(F)$ was measured over the area of the PSCs cell body, and the relative changes in fluorescence intensity were expressed as

$$
\Delta F / F=\left(F-F_{\text {rest }}\right) / F_{\text {rest }} .
$$

Local application of $\mathrm{KCl}(25 \mathrm{~mm})$ on PSCs was performed using micropipettes (tip diameter, 2-3 $\mu \mathrm{m}$ ). The same solution used to perfuse the preparation was used to prepare the $\mathrm{KCl}$ solution. This ensured that the only difference between the locally applied solution and the perfusion solution was the presence of $\mathrm{KCl}$. The tip of the pipette was positioned close to the PSCs soma under visual control at high magnification (40× objective), and $\mathrm{KCl}$ was applied with a $100 \mathrm{msec}$ pulse of positive pressure applied to the pipette (5-10 PSI) with a Picospritzer II (General Valve, Fairfield, NJ). In some experiments, external $\mathrm{Ca}^{2+}$ ions were omitted and replaced by $5 \mathrm{~mm} \mathrm{MgCl}_{2}$. In these experiments, the preparations were incubated for $30 \mathrm{~min}$ before any imaging was performed.

Imaging of $\mathrm{Ca}^{2+}$ entry in nerve terminals. Nerve terminals were loaded with the $\mathrm{Ca}^{2+}$ indicator fluo $3-\mathrm{AM}$ as indicated above, and muscle contractions were prevented by blocking cholinergic receptors with $\alpha$-bungarotoxin $(10 \mu \mathrm{g} / \mathrm{ml})$. In some instances, PSCs did not accumulate the $\mathrm{Ca}^{2+}$ indicator, leaving the nerve terminals available for $\mathrm{Ca}^{2+}$ imaging without any contamination by $\mathrm{Ca}^{2+}$ responses that could occur in the PSCs. On these nmj, no $\mathrm{Ca}^{2+}$ response could be obtained in PSCs using local applications of agonists that normally induce $\mathrm{Ca}^{2+}$ responses in these cells (ATP, adenosine, and muscarine) (Jahromi et al., 1992, 1993; Georgiou et al., 1994; Robitaille, 1995), and no fluorescence could be detected after incubation with the $\mathrm{Ca}^{2+}$ ionophore $\mathrm{Br}-\mathrm{A} 23187$ (data not shown). This indicates that $\mathrm{Ca}^{2+}$ responses obtained in these conditions were originating entirely from the presynaptic nerve terminals. Changes in fluorescence were measured using the line scan mode of the confocal and expressed as a percentage change, as indicated above. The scanning line was positioned over a linear portion of the nerve terminal that was perfectly in focus. The line scan procedure allows one to measure changes of fluorescence at $2 \mathrm{msec}$ intervals.

Staining and immunocytochemistry. Cutaneous pectoris muscles were dissected from the frogs and pinned down in a Sylgard-coated chamber. Preparations were fixed for $10 \mathrm{~min}$ with $3 \% \mathrm{p}$-formaldehyde prepared in normal frog Ringer's solution and rinsed 3 times for $30 \mathrm{~min}$ with frog Ringer's solution. Muscles were subsequently incubated in $0.3 \%$ Triton X-100 (Sigma, St. Louis, MO) in frog Ringer's solution for $30 \mathrm{~min}$ and 15 $\min$ in a solution containing $0.01 \%$ Triton $\mathrm{X}-100$ and $0.2 \%$ casein in frog Ringer's solution (solution A). Preparations then were incubated with mouse monoclonal anti- $\alpha 2 / \delta$ subunit of L-type $\mathrm{Ca}^{2+}$ channels (antibody mAb3007; Vandaele et al., 1987) (dilution 1/20 to $1 / 100$ in solution A) for $5 \mathrm{hr}$ at room temperature followed by $10 \mathrm{hr}$ at $4^{\circ} \mathrm{C}$. After three rinses of $30 \mathrm{~min}$ each with solution A, muscles were incubated at room temperature with a biotinylated donkey anti-mouse antibody (dilution 1:200, Jackson) for $60 \mathrm{~min}$ followed by three rinses for $20 \mathrm{~min}$ with solution A. The preparations were incubated with fluorescein isothiocyanate- 
conjugated streptavidin ( $20 \mu \mathrm{g} / \mathrm{ml}$; Molecular Probes) for $2 \mathrm{hr}$ in the dark, at room tempcraturc. No labeling was obscrved when the primary antibody was omitted. In some experiments, the periodate-lysine-p-formaldehyde (PLP) fixative was used (McLean and Nakane, 1974). The fixative contained $0.01 \mathrm{M} \mathrm{Na}^{+} m$-periodate, $75 \mathrm{~mm}$ lysine, and $2 \% p$-formaldehyde in a final concentration of $0.037 \mathrm{M}$ phosphate buffer, $\mathrm{pH} 7.4$. Phosphate buffer $(0.1 \mathrm{M}), \mathrm{pH} 7.4$, was used throughout the procedures when PLP was used as a fixative. Similar results were obtained with both fixatives.

To locate endplate areas, preparations were incubated with tetramethyl-rhodamine isothincyanate-conjugated peanut agglutinin lectin (TRITC-PNA; $15 \mu \mathrm{g} / \mathrm{ml}$, Sigma) in the dark for $10 \mathrm{~min}$. In some experiments, cholinergic receptors (AChR) were labeled with TRITC-conjugated $\alpha$-bungarotoxin ( $\alpha$-BuTx-TRITC, Molecular Probes) $(20 \mu \mathrm{g} / \mathrm{ml})$ for $30 \mathrm{~min}$.

Preparations were mounted onto glass slides in a solution of Slowfade antifade reagent (Molecular Probes) to reduce photobleaching. In double-labeled preparations, we used the dual wavelength configuration of the BioRad 600 confocal microscope. This configuration uses a $514 \mathrm{~nm}$ excitation wavelength, one photomultiplier tube detecting the green emitted light selected by a band pass filter $(514-550 \mathrm{~nm})$, and the second photomultiplier tube detecting the red emitted light selected hy a low pass filter (cutoff at $590 \mathrm{~nm}$ ). Green and red images acquired simultaneously are either presented separately or as one image where the red and green images are superimposed to reveal the relative spatial distribution of the two labels. Observations were performed using a $40 \times$ oil immersion lens (Nikon, 1.3 N.A.).

Labeling with fluorescent phenylalkylamine. In some experiments, the location of L-type $\mathrm{Ca}^{2+}$ channels was revealed using boron dipyrromethane difluoride-conjugated phenylalkylamine [(-)DM-BODIPY-PAA, which fluoresces green; Molecular Probes] (Knaus et al., 1992). Live muscles were incubated with 50-500 nM (-)DM-BODIPY-PAA (prepared in frog Ringer's solution) for $8 \mathrm{~min}$ at room temperature and then rinsed with frog Ringer's solution. The (-)DM-BODIPY-PAA solution was prepared a few minutes before its use. The labeling was observed with a $40 \times$ water immersion lens under the confocal microscope within the next 20 min after the incubation.

Enzymatic treatment of presynaptic nerve terminals and PSCs. In some experiments, presynaptic nerve terminals and PSCs were treated with collagenase to facilitate their removal from muscle fibers (Betz and Sakmann, 1971; Peper and MacMahan, 1972; Robitaille et al., 1990). Muscles were dissected out from the frogs and pinned down in a Sylgardcoated chamber, and AChRs were blocked with unlabeled $\alpha$-BuTx (20 $\mu \mathrm{g} / \mathrm{ml})$ to prevent possible muscle contractions during the collagenase treatment and mechanical displacement. Preparations also were stained with TRITC-PNA. Muscles were treated with a solution of $1666 \mathrm{U} / \mathrm{m}$ ] collagenase type IX (Sigma) for $60-70 \mathrm{~min}$ at room temperature. The reaction was stopped by an incubation with cold $\left(4^{\circ} \mathrm{C}\right) 0 \mathrm{Ca}^{2+} / 5 \mathrm{Mg}^{2+}$ frog Ringer's solution for $5 \mathrm{~min}$, and the preparations then were placed in normal Ringer's solution. Under precisc visual control, cell bodics of PSCs were sucked in a micropipette with a large tip (7-10 $\mu \mathrm{M})$ and gently pulled away from the endplate area until completely removed. This maneuver was considered successful if no sign of PSC cell bodies and nerve terminal remained at the endplate area when observed with transmitted light. In addition, peanut agglutinin (PNA) labeling was displaced with the nerve terminal and PSCs, because the proteoglycan labeled by the lectin is attached to the basal lamina (Ko, 1987). Preparations then were incubated with (-)DM-BODIPY-PAA, as described above.

Cross sections of nmj. Localization of $\mathrm{Ca}^{2+}$ channels around the nerve terminal and PSCs was examined using cross sections of nmj. Preparations were processed for L-type $\mathrm{Ca}^{2+}$ channel labeling and incubated with TRITC.PNA, as indicated above. Preparations then were frozen and mounted in OCT (Miles Laboratories, Naperville, IL). Cross sections (20 $\mu \mathrm{M}$ ) were made with a cryotome and collected on microscope slides. The sections were observed with the confocal microscope using the dual wavelength combination, as indicated above.

Denervation of nmj. For denervation of cutaneous pectoris muscles, frogs were anesthetized with MS-222 (tricaine, $0.3 \mathrm{mg} / \mathrm{gm}$ frog body weight) dissolved in frog Ringer's solution and injected in one of the lymphatic bags (total volume injected, between 100 and $200 \mu \mathrm{l}$ ). A small incision was made in the skin, and the motor nerve of one cutaneous pectoris muscle was cut off with minimum damage to the muscle blood supply. The contralateral muscle was used as a nondenervated control. The incision then was sewn in place using silk sutures. The frogs recovered in a wet environment for 6 or $7 \mathrm{~d}$. The animals then were killed by double pithing, and cutaneous pectoris muscles were dissected out from the frogs. Both muscles, denervated and nondenervated, were processed in parallel. To ascertain that no nerve terminal remained after dencrvation, live preparations were incubated for $1 \mathrm{~min}$ with 4-Di-2-Asp $(10 \mu \mathrm{M}$ in normal frog Ringer's solution). This stain labels specifically live presynaptic nerve terminals (Magrassi et al., 1987). Preparations also were stained with TRITC-PNA, as indicated above. Images were obtained with the dual wavelength configuration of the confocal microscope using a water immersion lens (40x Olympus). After these observations, muscles were fixed and processed for immunocytochemistry of L-type $\mathrm{Ca}^{2+}$ channels as indicated above. The same nmj then were found and imaged for the presence of $\mathrm{Ca}^{2+}$ channels.

\section{RESULTS}

The presence of L-type $\mathrm{Ca}^{2+}$ channels at the frog nmj first was studied by measuring changes of intracellular $\mathrm{Ca}^{2+}$ in presynaptic nerve terminals and PSCs.

\section{L-type $\mathrm{Ca}^{2+}$ channel agonist and antagonist do not change $\mathrm{Ca}^{2+}$ entry in presynaptic nerve terminals}

The presence of $\mathrm{L}$-type $\mathrm{Ca}^{2+}$ channels in presynaptic nerve terminals was studied by measuring the effects of agonist and antagonist on nerve-evoked entry of $\mathrm{Ca}^{2+}$. Figure $2 A$ illustrates a nerve terminal loaded with the fluorescent $\mathrm{Ca}^{2+}$ indicator fluo $3 . \mathrm{Ca}^{2+}$ changes evoked by a brief train of stimuli $(100 \mathrm{~Hz}, 250 \mathrm{msec})$ were measured on the nerve terminal branch at the top of the figure using the line scan mode of the confocal microscope. Figure $2 B$ shows $\mathrm{Ca}^{2+}$ responses in normal external $\mathrm{Ca}^{2+}$ (control), in presence of the L-type $\mathrm{Ca}^{2+}$ channel blocker nimodipine (2.5 $\mu \mathrm{M})$, and in presence of the $\mathrm{N}$-type $\mathrm{Ca}^{2+}$ channel blocker $\omega$-CgTx $(1 \mu \mathrm{M})$. Nimodipine had no effect on nerve terminal $\mathrm{Ca}^{2+}$ responses, whereas $\omega$-CgTx completely and irreversibly blocked nerve-evoked $\mathrm{Ca}^{2+}$ entry. Similarly, the agonist enantiomer of Bay K 8644, (-)S Bay K 8644 (van Amsterdam et al., 1989; Ravens and Schöpper, 1990), had no effect on the entry of $\mathrm{Ca}^{2+}$ in the nerve terminal (Fig. $2 C, D$ ) and did not modify the resting level of fluorescence in the nerve terminal (data not shown). However, $\omega$-CgTx $(1 \mu \mathrm{M})$ blocked all $\mathrm{Ca}^{2+}$ entry evoked by nerve stimulations. The lack of effect of $\mathrm{L}$-type $\mathrm{Ca}^{2+}$ channel agonist and antagonist is probably not attributable to the inability of the drugs to bind to the channels in a nondepolarized condition, because no additional effects were observed when nerve terminals were tonically depolarized by increasing external $\mathrm{K}^{+}$concentration $(5 \mathrm{~mm}$ ) (data not shown). Hence, the results suggest that L-type $\mathrm{Ca}^{2+}$ channels are not present in nerve terminals and are not involved in the transient entry of $\mathrm{Ca}^{2+}$ induced by an action potential.

\section{Functional L-type $\mathrm{Ca}^{2+}$ channels at PSCs}

To test for the presence of functional L-type $\mathrm{Ca}^{2+}$ channels, changes of intracellular level of $\mathrm{Ca}^{2+}$ were monitored after membrane depolarization induced by local applications of $\mathrm{KCl}$. Figure $3 A-C$ illustrates typical $\mathrm{Ca}^{2+}$ responses elicited by $\mathrm{KCl}$ in the presence or absence of external $\mathrm{Ca}^{2+}$. Figure $3 A$ shows the $\mathrm{Ca}^{2+}$ level in four PSCs at rest in $0 \mathrm{Ca}^{2+} / 5 \mathrm{Mg}^{2+}$ before local application of $\mathrm{KCl}$. In Figure $3 B, \mathrm{KCl}(25 \mathrm{~mm})$ was applied and the image taken. No $\mathrm{Ca}^{2+}$ responses were elicited by $\mathrm{KCl}$ when external $\mathrm{Ca}^{2+}$ was absent. The size of $\mathrm{Ca}^{2+}$ responses was on average only $23 \pm 12 \%$ ( 3 muscles, 16 cells). However, after return to normal concentration of external $\mathrm{Ca}^{2+}$, local application of $\mathrm{KCl}$ now induced $\mathrm{Ca}^{2+}$ responses in the same four cells (Fig. $3 \mathrm{C}$ ). $\mathrm{KCl}$ evoked $\mathrm{Ca}^{2+}$ responses were on average $125 \pm 23 \%$ ( 3 muscles, 12 cells), which is statistically different from the value obtained in absence of $\mathrm{Ca}^{2+}(p<0.05$, Student's paired $t$ test $)$. This indicates that depolarization by $\mathrm{KCl}$ induces entry of $\mathrm{Ca}^{2+}$, possibly through $\mathrm{Ca}^{2+}$ channels. It is unlikely that $\mathrm{KCl}$-induced responses 

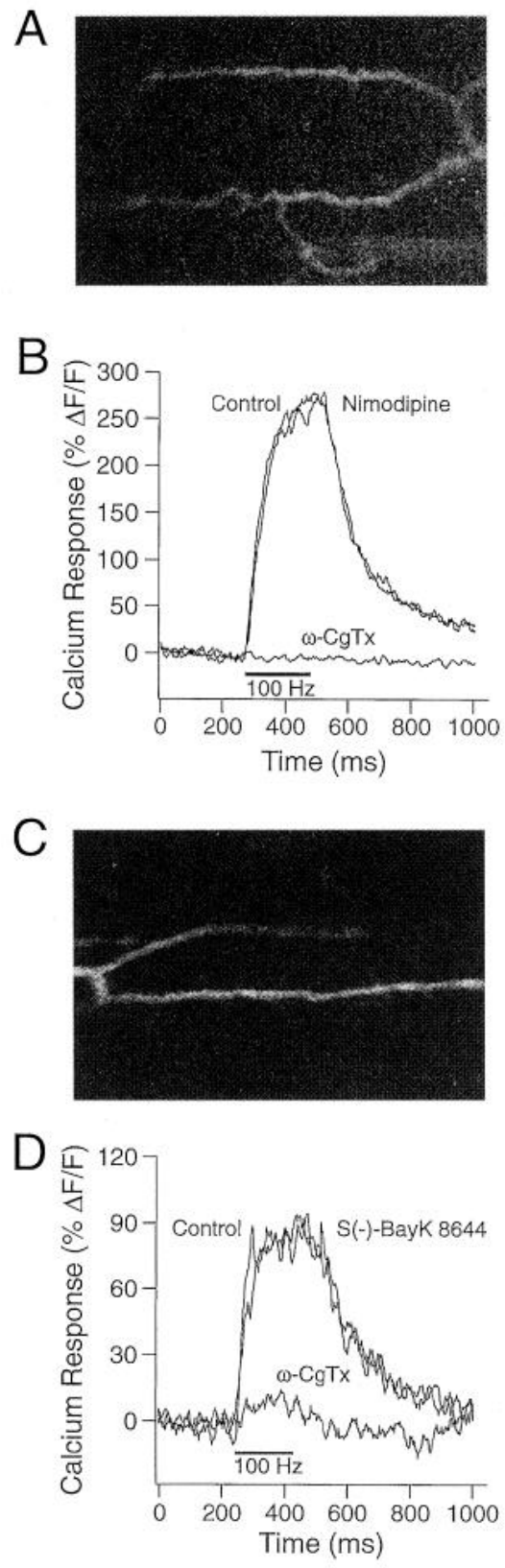

Figure 2. $\mathrm{Ca}^{2+}$ responses in nerve terminals are not affected by L-type $\mathrm{Ca}^{2+}$ channel agonist and antagonist. $A$, Confocal image of a frog nerve terminal loaded with the fluorescent $\mathrm{Ca}^{2+}$ indicator fluo 3. PSCs of this nmj were not loaded with the $\mathrm{Ca}^{2+}$ indicator. $B$, Changes of fluorescence evoked by nerve stimulations $(100 \mathrm{~Hz}, 250 \mathrm{msec})$ were detected using the line scan mode of the confocal. $\mathrm{Ca}^{2+}$ responses were obtained in normal Ringer's solution (control) $20 \mathrm{~min}$ after addition of $2.5 \mu \mathrm{M}$ nimodipine and $20 \mathrm{~min}$ after addition of $1 \mu \mathrm{M} \omega-\mathrm{CgTx}$. Note that nimodipine had no effect on the $\mathrm{Ca}^{2+}$ response, whereas $\omega$-CgTx completely blocked it. $C$, Confocal image of a frog nerve terminal loaded with the fluorescent $\mathrm{Ca}^{2+}$ indicator fluo 3. PSCs of this nmj were not loaded with the $\mathrm{Ca}^{2+}$ indicator. Different preparation than in $A . D$, Changes of fluorescence evoked by nerve stimulations $(100 \mathrm{~Hz}, 250$ msec) were detected using the line scan mode of the confocal. $\mathrm{Ca}^{2+}$ responses were obtained in normal Ringer's solution (control), $20 \mathrm{~min}$ after addition of $50 \mu \mathrm{M}(-) \mathrm{S}$ Bay K 8644 and $20 \mathrm{~min}$ after addition of $1 \mu \mathrm{M} \omega$-CgTx. Note that $(-) \mathrm{S}$ Bay K 8644 had no effect on the $\mathrm{Ca}^{2+}$ response, whereas $\omega$-CgTx blocked it. Complete blockade with $\omega$-CgTx was achieved $10 \mathrm{~min}$ later (data not shown). in PSCs were caused by the release of neurotransmitter substances induced by nerve terminal depolarization, because similar responses in PSCs were observed when $\mathrm{Ca}^{2+}$ entry in nerve terminal was blocked by $\omega$ - $\operatorname{CgTx}$ (data not shown; see also Jahromi et al., 1992)

If $\mathrm{Ca}^{2+}$ entry is dependent on $\mathrm{Ca}^{2+}$ channel opening, it should be prevented by the use of $\mathrm{Ca}^{2+}$ channel blockers. In the presence of $\mathrm{Cd}^{2+}(20 \mu \mathrm{M})$, a nonspecific blocker of $\mathrm{Ca}^{2+}$ channels (Ritchie, 1992), $\mathrm{Ca}^{2+}$ responses evoked by local applications of $\mathrm{KCl}(25$ $\mathrm{mm})$ were abolished $(34 \pm 17 \% ; 3$ muscles, 19 cells; $p<0.05$, Student's paired $t$ test). This indicates that $\mathrm{Ca}^{2+}$ entry is mediated by opening of $\mathrm{Ca}^{2+}$ channels.

Specific L-type $\mathrm{Ca}^{2+}$ channel blockers were used to characterize further the type of channels present on the PSCs. Figure $3 E$ shows the $\mathrm{Ca}^{2+}$ fluorescence in two PSCs at rest in the presence of nimodipine $(2.5 \mu \mathrm{M})$ and Figure $3 F$ shows the same cells after local application of $\mathrm{KCl}$. In the presence of nimodipine $(2-20 \mu \mathrm{M})$, $\mathrm{Ca}^{2+}$ responses evoked by local application of $\mathrm{KCl}(25 \mathrm{~mm})$ were abolished. On average, the responses were only $21 \pm 12 \%$ (3 muscles, 15 cells), which is significantly different from the responses elicited by $\mathrm{KCl}$ in absence of nimodipine $(p<0.05$, Student's paired $t$ test). However, $\mathrm{KCl}$ induced $\mathrm{Ca}^{2+}$ responses in the same cells after washout of nimodipine (Fig. $3 G$ ). Similar results were obtained when the antagonist enantiomer of Bay $\mathrm{K}$ 8644 (van Amsterdam et al., 1989; Ravens and Schöpper, 1990), $(+) \mathrm{R}$ Bay K $8644(2 \mu \mathrm{M})$, was used ( $23 \pm 9 \% ; 2$ muscles, 11 cells) (see also Robitaille, 1995). These results allow us to conclude that the entry of $\mathrm{Ca}^{2+}$ induced by membrane depolarization is mediated by the activation of L-type $\mathrm{Ca}^{2+}$ channels.

\section{L-type $\mathrm{Ca}^{2+}$ channels are located at the endplate}

To locate $\mathrm{Ca}^{2+}$ channels, preparations were incubated with a monoclonal antibody, mAb3007, directed against the $\alpha 2 / \delta$ subunit component in the L-type $\mathrm{Ca}^{2+}$ channel molecular complex (Vandaele et al., 1987). This antibody has been shown to bind to frog muscle membranes (Vandaele et al., 1987). Endplates labeled with TRITC-PNA first were located with the fluorescent microscope and then examined in detail using the confocal microscope. A typical $\mathrm{nmj}$ is illustrated in Figure $4 A$. Labeling of the $\alpha 2 / \delta$ subunit of $\mathrm{Ca}^{2+}$ channels revealed the presence of several spots aligned at irregular intervals along the endplate, with a lower density at the PSCs soma (arrow). Staining can be detected underneath the cell body area when nmj are observed on the side of muscle fibers (data not shown). Muscle fibers also were labeled at the level of the $\mathrm{Z}$ bands where L-type $\mathrm{Ca}^{2+}$ channels are present (Jorgensen et al., 1989; Flucher et al., 1990; Toutant et al., 1990). However, this staining cannot be seen in Figure $4 A$ because of the narrow depth of field caused by the confocal effect. No staining was observed on myelinating Schwann cells or on other cellular elements of the nerve-muscle preparation.

To rule out the possibility that the labeling pattern observed was attributable to trapping of the antibody in the synaptic cleft, the membrane permeabilization step was omitted (no Triton X-100 added) and the labeling procedure performed as described. Moreover, because the epitope recognized by antibody mAb3007 was intracellular (Vandaele and Rieger, 1994), the lack of permeabilization should prevent the labeling if it was not caused by trapping of the antibodies in the synaptic cleft. Preparations were fixed with PLP fixative to reduce nonspecific labeling. No staining could be observed at the endplate area or in the muscle fiber (Fig. $4 B$ ) indicating that the access to the interior of the cell was necessary to label $\mathrm{Ca}^{2+}$ 

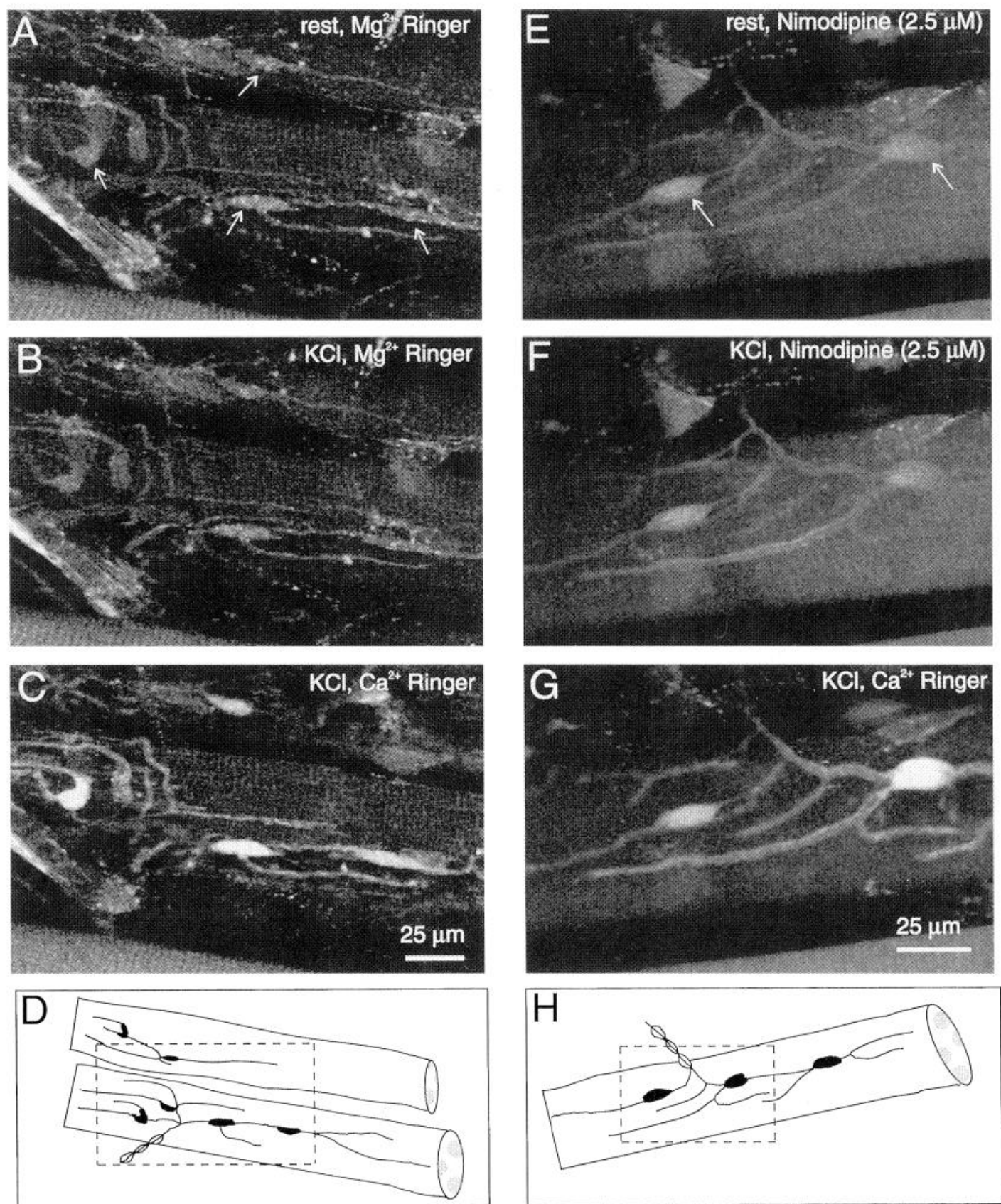

Figure 3. $\mathrm{Ca}^{2+}$ entry in PSCs occurs through L-type $\mathrm{Ca}^{2+}$ channels. $A-C$, Confocal images of 4 PSCs (arrows) at two nmj at rest in absence of external $\mathrm{Ca}^{2+}(A)$, immediately after local application of $\mathrm{KCl}(25 \mathrm{~mm})$ in absence of external $\mathrm{Ca}^{2+}(B)$, and immediately after local application of $\mathrm{KCl}(25 \mathrm{mM})$ in presence of external $\mathrm{Ca}^{2+}(C)$. No $\mathrm{Ca}^{2+}$ responses could be evoked by $\mathrm{KCl}$ in absence of external $\mathrm{Ca}^{2+}$. $D$, Diagram illustrating the nmj presented in $A-C$. The box represents the area scanned by the confocal microscope. $E-G$, Confocal images of two PSCs (arrows) at an nmj at rest in the presence of nimodipine $(2.5 \mu \mathrm{M})(E)$, immediately after local application of $\mathrm{KCl}(25 \mathrm{mM})$ in presence of nimodipine $(2.5 \mu \mathrm{M})(F)$, and immediately after local application of $\mathrm{KCl}(25 \mathrm{~mm})$ after 20 min of perfusion with normal frog Ringer's solution $(G)$. No $\mathrm{Ca}^{2+}$ responses were evoked by $\mathrm{KCl}$ in presence of $\mathrm{L}$-type $\mathrm{Ca}^{2+}$ channel blockers. $H$, Diagram illustrating the nmj presented in $E-G$. The box represents the area scanned by the confocal microscope.

channels and rule out the possibility that the labeling at the endplate area could be caused by trapping of the antibody in the synaptic cleft.

\section{Labeling of L-type $\mathrm{Ca}^{2+}$ channels by a phenylalkylamine}

$\mathrm{Ca}^{2+}$ channels are composed of several subunits (Hofmann, 1994). The use of antibody $\mathrm{mAb} 3007$ reveals the location of the $\alpha 2 / \delta$ subunit of the $\mathrm{Ca}^{2+}$ channels, which could be present in other types of $\mathrm{Ca}^{2+}$ channels (Witcher et al., 1993). Because the $\alpha 1$ subunit is unique to the L-type $\mathrm{Ca}^{2+}$ channel, we wondered whether labeling of the $\alpha 1$ subunit of the channels would reveal a pattern similar to the $\alpha 2 / \delta$ subunit immunoreactivity. The $\alpha 1$ subunit of L-type $\mathrm{Ca}^{2+}$ channels was labeled with a fluorescent PAA, an L-type $\mathrm{Ca}^{2+}$ channel antagonist (Knaus et al., 1992). An endplate labeled with (-)DM-BODIPY-PAA is illustrated in Figure $4 C$. Similar to the antibody labeling, the staining observed with (-)DM-BODIPY-PAA was found at the nerve endplate and $\mathrm{Z}$ bands of the muscle fibers. Moreover, (-)DM-BODIPY-PAA labeling at the endplate revealed a spotty pattern similar to the 

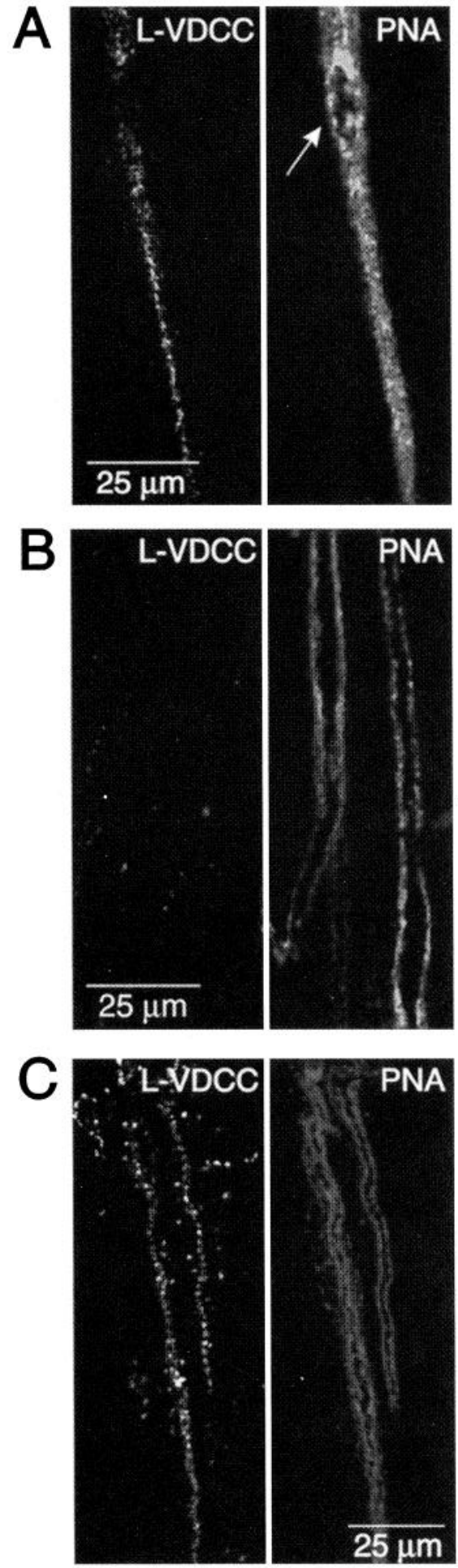

Figure 4. Labeling of L-type $\mathrm{Ca}^{2+}$ channels is located at the motor endplate. $A$, Labeling of $\alpha 2 / \delta$ subunit with the antibody mAb3007 ( $L-V D C C)$ revealed a spotty and irregular pattern. The $\alpha 2 / \delta$ immunoreactivity was found only at the motor endplate as indicated by the presence of PNA staining $(P N A)$. Note that almost no labeling was observed in the cell body area of the PSCs (arrow). $B$, Labeling with the antibody $\mathrm{mAb} 3007$ in absence of membrane permeabilization with Triton X-100 ( $L-V D C C)$. Note the absence of labeling at the endplate area revealed by the presence of the TRITC-PNA staining (PNA). The antibody recognizes an intracellular epitope. $C$, Labeling of $\mathrm{L}$-type $\mathrm{Ca}^{2+}$ channels with (-)DM-BODIPY-PAA $(L-V D C C)$ showed an irregular and spotty pattern comparable to the one observed with the antibody labeling. The (-)DM-BODIPY-PAA labeling also is restricted to the endplate area indicated by the presence of PNA staining. one observed with antibody mAb3007. The labeling observed with (-)DM-BODIPY-PAA was abolished when the preparations were preincubated for $30 \mathrm{~min}$ with verapamil, an L-type $\mathrm{Ca}^{2+}$ channel antagonist ( $50 \mu \mathrm{M}$; Sigma), indicating that the labeling was caused by the binding to L-type $\mathrm{Ca}^{2+}$ channels.

Although the use of a confocal microscope allows one to examine a thin portion of the sample, the small size of the nerve terminal and the PSC processes precludes any conclusion on the exact location of L-type $\mathrm{Ca}^{2+}$ channels at the endplate area. Thus, the next series of experiments was aimed at determining on which cellular element of the nmj the $\mathrm{Ca}^{2+}$ channels are located.

\section{L-type $\mathrm{Ca}^{2+}$ channel labeling remains in absence of nerve terminals}

If $\mathrm{L}$-type $\mathrm{Ca}^{2+}$ channels are located in the presynaptic terminals, no labeling should be observed when the nerve terminals are absent. To test that possibility, cutaneous pectoris muscles were denervated for 6-7 d before labeling $\mathrm{Ca}^{2+}$ channels. This period is sufficient to induce the degeneration of a majority of nerve terminals (Birks et al., 1960; Cohen et al., 1991). The vital dye 4-Di-2-ASP, which labels presynaptic terminals (Magrassi et al., 1987), was used to test for the presence of nerve terminals. Live preparations were incubated with 4-Di-2-ASP $(10 \mu \mathrm{M})$, endplate areas were disclosed using TRITCPNA, and images of 4-Di-2-ASP and PNA labeling were obtained simultaneously with the confocal microscope. After this observation, the preparations were fixed and $\mathrm{Ca}^{2+}$ channels labeled with antibody mAb3007. After fixation, 4-Di-2-ASP labeling disappears. An example of an endplate from an intact muscle (i.e., not denervated) is presented in Figure $5 A$. All nmj identified with the lectin (Fig. $5 A$, $P N A$ ) showed labeling of nerve terminals with 4-Di-2-ASP, and the same nmj could be found after the immunocytochemistry procedure, which revealed the presence of L-type $\mathrm{Ca}^{2+}$ channels (Fig. $5 A$, $L-V D C C)$.

When the same procedure was performed on denervated muscles, no presynaptic nerve terminal staining was observed (Fig. $5 B$, 4-Di-2-ASP) at any of the nmj identified with the lectin (Fig. $5 B$, $P N A$ ), indicating that presynaptic terminals were absent. However, labeling of $\mathrm{L}$-type $\mathrm{Ca}^{2+}$ channels (Fig. $5 B, L-V D C C$ ) still was observed in all $\mathrm{nmj}$ identified. Although the presence of L-type $\mathrm{Ca}^{2+}$ channels in presynaptic nerve terminals cannot be completely ruled out, the persistence of L-type $\mathrm{Ca}^{2+}$ channel immunoreactivity after denervation suggests that these channels primarily are located in structures other than the presynaptic terminals of the frog nmj.

\section{L-type $\mathrm{Ca}^{2+}$ channel labeling is displaced by removal of PSCs}

If $\mathrm{L}$-type $\mathrm{Ca}^{2+}$ channels are not located at the presynaptic terminals, only two possibilities remain: in the plasma membrane of the muscle fiber or at the PSCs. To discriminate between these two possibilities, PSCs were removed mechanically from the endplate area after enzymatic digestion of the connective tissue. In this situation, if L-type $\mathrm{Ca}^{2+}$ channels are located in the PSCs, no labeling should be observed at the endplate area. On the other hand, the labeling should remain if the channels are located in the plasma membrane of the muscle fiber. Figure $6 A$ shows an nmj labeled with TRITC-PNA after collagenase treatment. In Figure $6 B$, a PSC of the same nmj is being pulled away with a micropipette until it is completely removed from the endplate area (Fig. $6 C)$. The absence of lectin staining confirms that nerve terminal and PSCs were removed from this area. As shown in Figure $6 D$, no $\mathrm{Ca}^{2+}$ channels labeled with (-)DM-BODIPY-PAA were ob- 
served at the nmj area where PSCs and nerve terminal were removed, but were present on a branch of the same nmj that was not mechanically removed. In all cells tested, no labeling of $\mathrm{Ca}^{2+}$ channels could be observed after enzymatic treatment with collagenase and mechanical removal of the PSCs. Therefore, these results indicate that L-type $\mathrm{Ca}^{2+}$ channels are located in the PSCs and not in the plasma membrane of the muscle fiber. The lack of labeling is not attributable to the removal of $\mathrm{Ca}^{2+}$ channels by the enzymatic treatment alone, because $\mathrm{Ca}^{2+}$ channel staining still was observed at $Z$ bands and at endplates where PSCs were not removed mechanically. It also is unlikely that $\mathrm{Ca}^{2+}$ channels were removed mechanically from the muscle fiber, because AChRs remained in place after such procedure, even though $\mathrm{L}$-type $\mathrm{Ca}^{2+}$ channel labeling was removed (data not shown).

\section{L-type $\mathrm{Ca}^{2+}$ channels are clustered between bands of AChRs}

The irregular pattern of distribution of L-type $\mathrm{Ca}^{2+}$ channels is very reminiscent of the distribution of finger-like processes of the PSCs and, hence, suggests that these channels are located at the processes. If this hypothesis is correct, spots of L-type $\mathrm{Ca}^{2+}$ channel labeling should be located at irregular intervals between the bands of the AChRs. L-type $\mathrm{Ca}^{2+}$ channels labeled with antibody mAb3007 (L-VDCC) and AChRs labeled with TRITCconjugated $\alpha$-BuTx ( $\alpha$-BuTx) at the same endplate were observed simultaneously with the confocal microscope. The typical banding pattern at $1 \mu \mathrm{m}$ intervals of $\mathrm{AChRs}$ was observed. If L-type $\mathrm{Ca}^{2+}$ channel and AChRs labeling patterns are identical, superimposition of the two images should produce a yellow image (green and red give yellow). Conversely, if the two patterns are different, the superimposed image should present mainly green and red pixels. As illustrated in Figure $7 A$ (merged) and $B$, superimposition of the two images shows that the majority of $\mathrm{L}$-type $\mathrm{Ca}^{2+}$ channel spots lie in between bands of AChRs. The overlap between L-type $\mathrm{Ca}^{2+}$ channel labeling and bands of labeled AChRs is consistent with the interposition of PSC fingers between nerve terminals and muscle fibers near active zones (Herrera et al., 1985).

\section{L-type $\mathrm{Ca}^{2+}$ channels are not clustered all around the PSCs}

The labeling pattern of L-type $\mathrm{Ca}^{2+}$ channels is consistent with the hypothesis that these channels are located in the finger-like processes of the PSCs, rather than distributed all around the circumference of PSCs. If this is the case, cross sections of nmj should reveal a discrete $\mathrm{Ca}^{2+}$ channel immunoreactivity in the synaptic cleft, and not an annulus of labeling around the PSCs. PNA was used as an indicator of the location of the synaptic cleft, because it labels a proteoglycan associated with the basal lamina (Ko, 1987). $\mathrm{Ca}^{2+}$ channels were labeled with the monoclonal antibody mAb3007. Figure 8 shows a cross section of an endplate double-labeled for L-type $\mathrm{Ca}^{2+}$ channels (green) and PNA (red). The green and red images were acquired simultaneously and are superimposed to show the relative position of each label. L-type $\mathrm{Ca}^{2+}$ channel immunoreactivity was limited to the synaptic cleft, colocalized with the lectin labeling (green and red give yellow) No labeling was observed elsewhere around the PSC. Thus, these results suggest that L-type $\mathrm{Ca}^{2+}$ channels are clustered at the finger-like processes of PSCs located near the transmitter release sites.

\section{DISCUSSION}

We showed in this study that L-type $\mathrm{Ca}^{2+}$ channels are not involved in nerve-evoked $\mathrm{Ca}^{2+}$ entry in nerve terminals of the frog nmj but are present and not evenly distributed along the perisynaptic glial cells. The mismatch between the irregular labeling pattern of L-type $\mathrm{Ca}^{2+}$ channels and the regular distribution of postjunctional folds, combined with the use of various experimental protocols, indicated that L-type $\mathrm{Ca}^{2+}$ channels are likely to be clustered at the finger-like processes of PSCs.

\section{L-type $\mathrm{Ca}^{2+}$ channels at PSCs of the frog $\mathrm{nmj}$}

The lack of effects of L-type $\mathrm{Ca}^{2+}$ channel agonist and antagonist on nerve-evoked $\mathrm{Ca}^{2+}$ responses in presynaptic terminals, as well as the characteristics of the labeling pattern of the channels, suggests that L-type $\mathrm{Ca}^{2+}$ channels are not located in the nerve terminals. Moreover, the complete and irreversible blockade of transmitter release by $\omega$-CgTx (Robitaille et al., 1993a) is a strong indication that there is only one type of $\mathrm{Ca}^{2+}$ channel regulating transmitter release, which is probably an N-type. Notwithstanding these observations, one cannot rule out completely that L-type $\mathrm{Ca}^{2+}$ channels are present in nerve terminals, because they could be present in low density not detected by the labeling assays and involved in other forms of modulation of transmitter release not related to action potentials.

The blockade of depolarization-induced $\mathrm{Ca}^{2+}$ responses in PSCs by L-type $\mathrm{Ca}^{2+}$ channel antagonists and not by the $\mathrm{N}$-type $\mathrm{Ca}^{2+}$ channel blocker $\omega$-CgTx (Jahromi et al., 1992) indicates that $\mathrm{Ca}^{2+}$ channels in PSCs are likely to be of the L-type. In addition, the persistence of the staining in absence of nerve terminals, combined with the mechanical displacement of the labeling, confirms that $\mathrm{L}$-type $\mathrm{Ca}^{2+}$ channels are primarily in PSCs rather than in the nerve terminal or the membrane of the muscle fiber. This conclusion also is supported by the labeling observed with the

Figure 5. Top left. L-type $\mathrm{Ca}^{2+}$ channel labeling remains in absence of presynaptic nerve terminals. $A$, False color images of a normal (innervated) frog nmj observed after staining of the nerve terminals with the vital dye 4-Di-2-ASP. The preparation also was stained with the lectin (PNA) to confirm the presence of the endplate area. The preparation was observed using the dual wavelength mode of the confocal. After the observations of 4-Di-2-ASP, the preparations were fixed and processed for immunocytochemistry to reveal the L-type $\mathrm{Ca}^{21}$ channels. The same nmj was found and imaged for the location of $\mathrm{Ca}^{2+}$ channels $(L-V D C C)$. Note that the same nmj could be visualized for nerve terminal staining and $\mathrm{L}$-type $\mathrm{Ca}^{2+}$ channels. $B$, Neuromuscular junction from a $6 \mathrm{~d}$ denervated preparation on which the same procedure as in $A$ was applied. Note the presence of $\mathrm{L}$-type $\mathrm{Ca}^{2+}$ channel labeling $(L-V D C C)$ even though there was no evidence for any nerve terminal staining with 4-Di-2-ASP.

Figure 7. Bottom. L-type $\mathrm{Ca}^{2+}$ channels are clustered between bands of AChRs. A, False color images showing L-type $\mathrm{Ca}^{2+}$ channels $(L-V D C C$, green $)$ and bands of $\mathrm{AChRs}(\alpha-B u T x$, red $)$. The two images are superimposed (merged) to illustrate the relative distribution of $\mathrm{L}-$ type $\mathrm{Ca}^{2+}$ channels and $\mathrm{AChRs}$. $B$, Enlargement of a portion of the nmj delimited by the box in $A$. Note that a majority of spots of ${\mathrm{L}-\mathrm{Ca}^{2+}}^{2}$ channels are located between bands of AChRs. Some spots do overlap and appear yellow (green and red gives yellow).

Figure 8. Top right. $\mathrm{Ca}^{2+}$ channels are clustered in the processes of PSCs in the synaptic cleft. False color image of a cross section of a frog nmj. Green and red images were acquired simultaneously and superimposed. $\mathrm{Ca}^{2+}$ channels (green) were labeled with antibody mAb3007 and the basal lamina was labeled with TRITC-PNA (red). The labeling of $\mathrm{Ca}^{2+}$ channels is confined in the synaptic cleft surrounded by the PN $\Lambda$ staining and appears yellow. $\mathrm{L}$-type $\mathrm{Ca}^{2+}$ channels are restricted to the fine processes and not all around PSCs. The diagram illustrating the cross section is presented with the box of the area scanned by the confocal. 

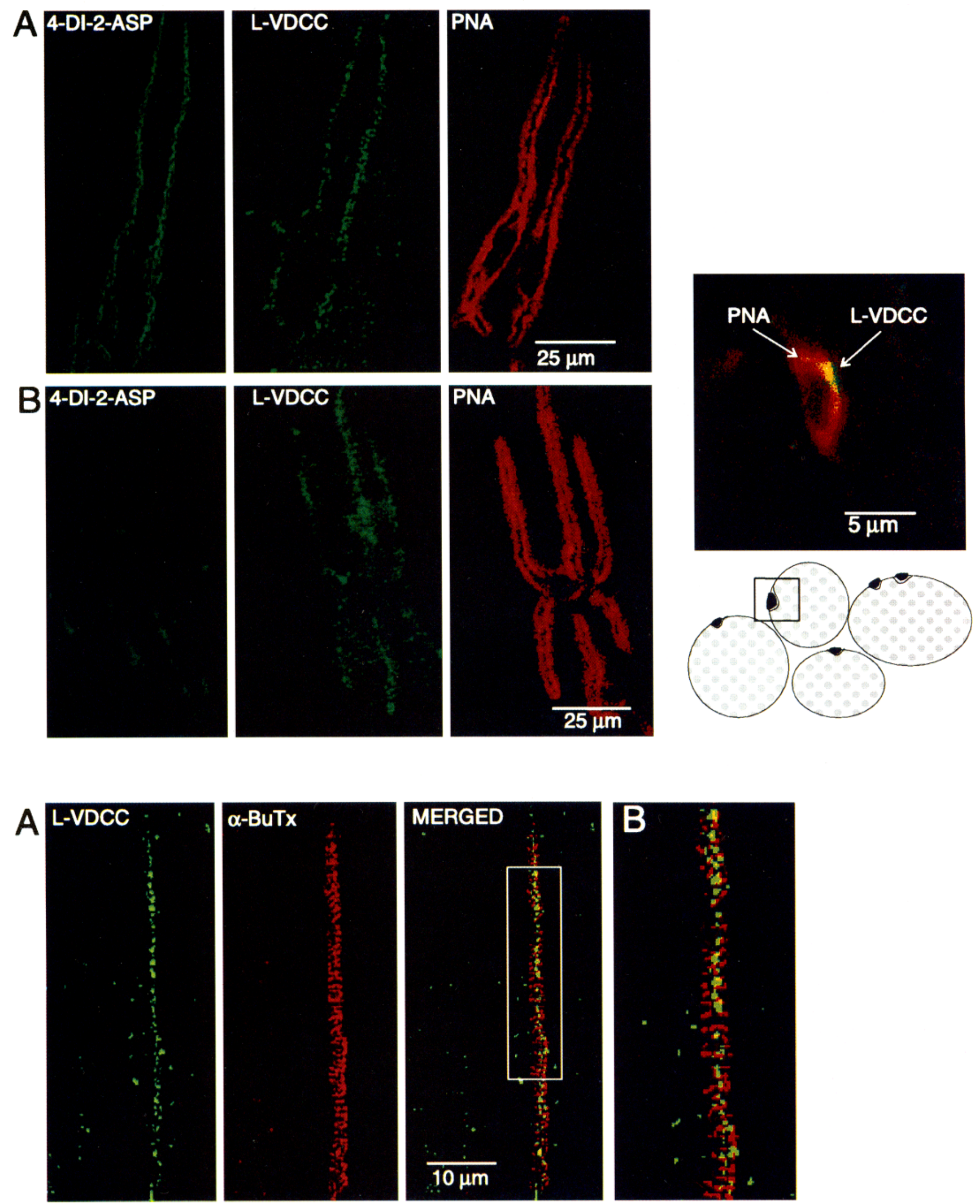

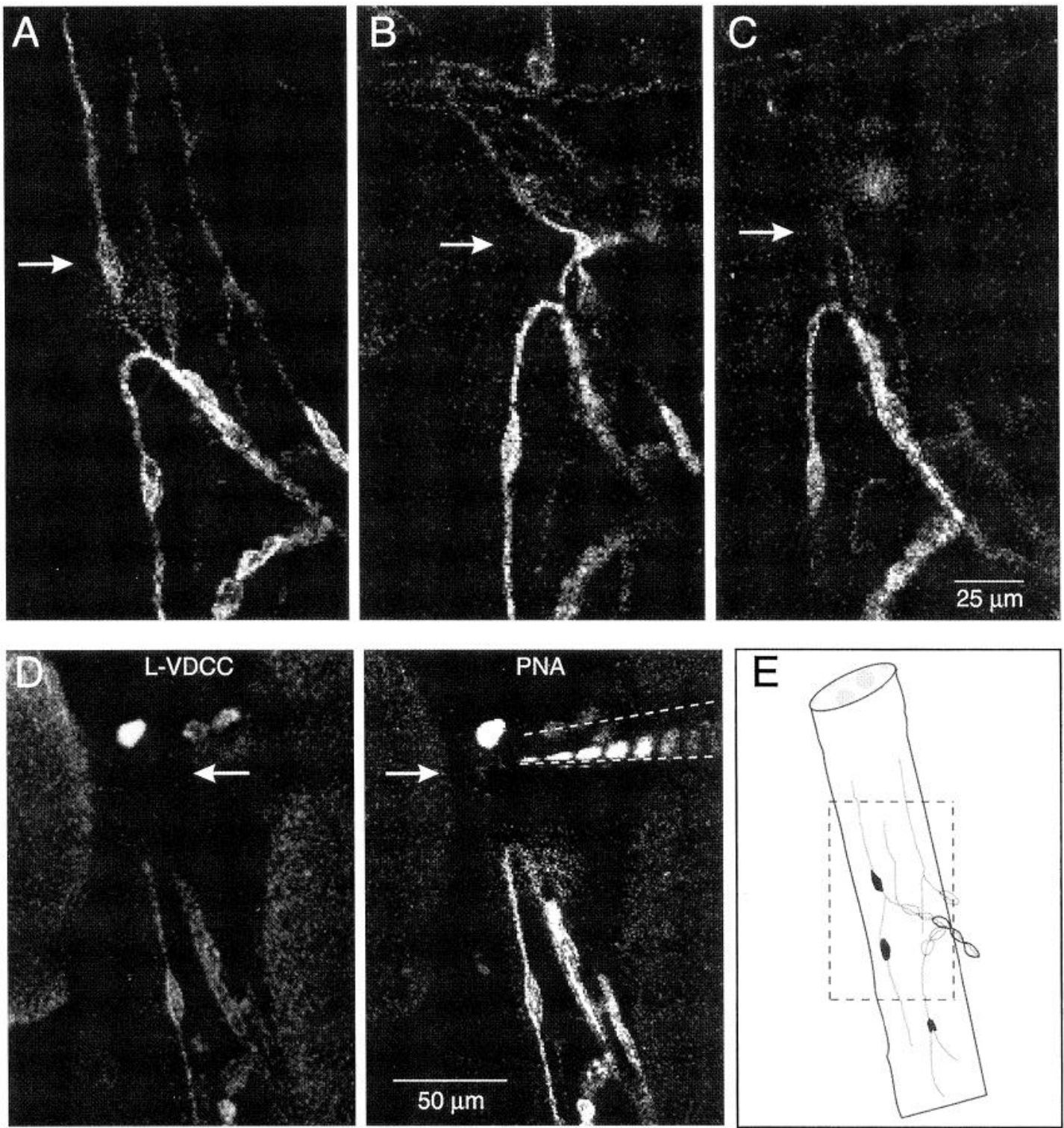

Figure 6. Removal of $\mathrm{Ca}^{2+}$ channels by mechanical displacement of PSCs. A, Frog nmj labeled with TRITC-PNA after collagenase treatment to digest connective tissue. The arrow points to the PSC that will be used to pull the presynaptic terminal and PSCs with a large micropipette. $B$, Same nmj when the PSC (arrow) is partially sucked in the micropipette. $C$, The nmj after complete removal of one branch. Note the absence of the PNA staining (arrow), which was removed with the connective tissue and the basal lamina. $D$, Labeling of L-type $\mathrm{Ca}^{2+}$ channels $(L-V D C C)$ with $(-)$ DM-BODIPY-PAA of the same nmj also labeled with PNA. Note the absence of any $\mathrm{Ca}^{2+}$ channel labeling at the site where the presynaptic terminal and PSCs were removed (arrow), although $\mathrm{Ca}^{2+}$ channel labeling is clearly visible at the other portion of the same nmj, which was not mechanically perturbed. Dotted lines indicate the position of the pipette, and the fluorescent dots are the remnants of the nmj sucked into the pipette. $E$, Diagram illustrating the nmj presented in $A-D$. The box represents the area scanned by the confocal microscope.

fluorescent PAA, a blocker of L-type $\mathrm{Ca}^{2+}$ channels. The presence of N-type $\mathrm{Ca}^{2+}$ channels at PSCs is unlikely because no labeling was observed on PSCs with $\omega$-CgTx (Robitaille et al., 1990; Cohen et al., 1991). The presence of L-type $\mathrm{Ca}^{2+}$ channels in PSCs is consistent with what is found in other types of glial cells, because this is one of the most common types of $\mathrm{Ca}^{2+}$ channels found in these cells (MacVicar, 1984; Barres et al., 1990; Verkhratsky et al., 1990; MacVicar et al., 1991; Ritchie, 1992; Kirischuk et al., 1995).

However, there is a possibility that the antibody mAb3007 also labels other types of $\mathrm{Ca}^{2+}$ channels, because the $\alpha 2$ subunit may be common to multiple types of channels, in particular, N-type $\mathrm{Ca}^{2+}$ channels (Witcher et al., 1993), and because these channels are likely to be present in presynaptic nerve terminals of frog $\mathrm{nmj}$ (Kerr and Yoshikami, 1984; Robitaille et al., 1990, 1993a,b; Cohen et al., 1991). This possibility is unlikely for several reasons. For instance, labeling of $\mathrm{N}$-type $\mathrm{Ca}^{2+}$ channels with $\omega$-CgTx shows a regular banding pattern of $1 \mu \mathrm{m}$, which matches the pattern of the cholinergic receptors labeled with fluorescent $\alpha$-BuTx, suggesting the presence of $\mathrm{Ca}^{2+}$ channels at release sites (Robitaille et al., 1990, 1993a,b; Cohen et al., 1991). However, in the present study, unlike the banding pattern of labeling with $\omega$-CgTx, the patterns observed with antibody mAb3007 or (-)DM-BODIPY-PAA were spotty, were not similar in pattern and shape to the cholinergic receptor staining and, finally, remained after disappearance of the presynaptic terminals. Finally, 
the presence of labeling at the $\mathrm{Z}$ bands of muscle fibers is a strong indication that the probes indeed did demonstrate the distribution of L-type $\mathrm{Ca}^{2+}$ channels (Jorgensen et al., 1989; Flucher et al., 1990; Toutant et al., 1990). The lack of labeling by antibody mAb3007 of $\mathrm{N}$-type $\mathrm{Ca}^{2+}$ channels in presynaptic nerve terminals may indicate that the $\alpha 2 / \delta$ subunit is not part of the presynaptic $\mathrm{Ca}^{2+}$ channel complex or that the subunit is present but different from the PSCs $\mathrm{Ca}^{2+}$ channel subunit. Alternatively, the threedimensional organization of the presynaptic $\mathrm{Ca}^{2+}$ channel complex is such that the antibody does not reach the $\alpha / 2 \delta$ subunit. Hence, we conclude that L-type $\mathrm{Ca}^{2+}$ channels are present at PSCs of the frog nmj.

\section{Subcellular distribution of receptors and channels in glia}

Several examples of the subcellular distribution of receptors and ion channels in various glial cell types have been described (Rawlins and Villegas, 1978; Newman, 1986; Cull-Candy et al., 1989; Wilson and Chiu, 1990; Chiu, 1991; Derouiche and Frotscher, 1991; Sontheimer and Waxman, 1993; Müller et al., 1994; Kirischuk et al., 1995). The common feature of these observations is the nonuniform distribution of channels and receptors, with a clear tendency for their location away from the cell body. Derouiche and Frotscher (1991) showed that the enzyme glutamine synthetase, responsible for glutamate degradation, was found in glial cell processes near glutamatergic synapses in rat hippocampus. Thus, it appears that glial cells present a specialized distribution of functional elements that allow them to perform specific tasks associated with neuronal activity. The results of the present study provide a description of the location of functional molecules at a synapse in situ. The mismatch between the spotty and irregular pattern of L-type $\mathrm{Ca}^{2+}$ channel labeling and the regular banding pattern of AChR staining, combined with the observations that $\mathrm{Ca}^{2+}$ channels are clustered in a glial structure located in the synaptic cleft, strongly suggests that L-type $\mathrm{Ca}^{2+}$ channels are located in PSC processes in close anatomical contact with the synapse and clustered near transmitter release sites. This possibility is supported further by the observation that some spots of $\mathrm{Ca}^{2+}$ channel labeling overlapped with a portion of AChR bands. Indeed, this overlap is consistent with the observation that a certain percentage of PSC processes partially covers active zones at the frog nmj (Herrera et al., 1985). Experiments using electron microscopy are in progress to confirm this possibility.

\section{Functional significance of $\mathrm{Ca}^{2+}$ channel location near the release sites}

Several effects of glial $\mathrm{Ca}^{2+}$ channel activation have been shown, and diverse roles such as modulating phosphorylation and dephosphorylation activity have been proposed, triggering release of substances (Martin, 1992) controlling myelin formation during the development of oligodendrocytes (Kirischuk et al., 1995) or regulating glial cell activity during seizure (MacVicar et al., 1991).

However, very little is known about glial $\mathrm{Ca}^{2+}$ channels around synapses. Smith (1992) modeled the effects of glial $\mathrm{Ca}^{2+}$ channel activation on the $\mathrm{Ca}^{2+}$ concentration in the synaptic cleft of a synapse in the central nervous system. The model indicates that such activation of glial $\mathrm{Ca}^{2+}$ channels would produce a local reduction of the cleft $\mathrm{Ca}^{2+}$ concentration and, because of the sensitivity of transmitter release to $\mathrm{Ca}^{2+}$, would result in a reduction in the amount of transmitter released. Such a mechanism may he present at the frog $\mathrm{nmj}$ hecause of the location of glial $\mathrm{Ca}^{2+}$ channels near transmitter release sites. In addition to their precise location, L-type $\mathrm{Ca}^{2+}$ channels at PSCs also are functional and modulated by a $\mathrm{P}_{2 \mathrm{X}}$ receptor after release of endogenous ATP during synaptic activity (Robitaille, 1995). However, because the size of the synaptic cleft at the nmj is much larger than at central synapses, this mechanism may not be as powerful here as it is suggested for a synapse of the central nervous system. Because $\mathrm{Ca}^{2+}$ is a ubiquitous second messenger controlling a large number of cellular functions, appealing alternatives, among others, would be that $\mathrm{Ca}^{2+}$ entry through L-type $\mathrm{Ca}^{2+}$ channels may regulate gene expression (Murphy et al., 1991) or trigger the release of substances susceptible to modulate transmitter release (Martin, 1992).

It has been shown that I,-type $\mathrm{Ca}^{2+}$ channel antagonists and agonists at mouse, lizard, and amphibian nmj modulated synaptic activity (Publicover and Duncan, 1979; Atchison and O'Leary, 1987; Lindgren and Moore, 1989; Ribera and Nastuk, 1989; Kawagoe et al., 1990). In light of the present results, one may suggest that the modulation of transmitter release by the pharmacological agents acting on L-type $\mathrm{Ca}^{2+}$ channels is mediated indirectly by modulating the activity of perisynaptic glial cells, which in turn would modify the activity of the synapse.

\section{Precise location of channels and receptors at PSCs: a glial "active zone"}

Glial cells may modulate synaptic activity, owing to their close anatomical contact with synapses and their sensitivity to neurotransmitters. For that purpose, it is important for the glial cellular elements involved in such action to be located near transmitter release sites (Derouiche and Frotscher, 1991; Smith, 1992). The discrete and precise location of $\mathrm{Ca}^{2+}$ channels at PSCs suggests the presence of an organized molecular machinery at perisynaptic glial cells such that other ion channels, receptors, and pumps also may be clustered at the processes, close to the sites of transmitter release. Hence, we propose a model in which functional molecules are located in the finger-like processes, highly organized elements strategically positioned to detect and perhaps modulate neurotransmitter release.

\section{REFERENCES}

Arslan P, Di Virgilio F, Beltrame M, Tsien RY, Pozzan T (1985) Cytosolic $\mathrm{Ca}^{2+}$ homeostasis in Ehrlich and Yoshida carcinomas. J Biol Chem 260:2719-2727.

Atchison WD, O'Leary SM (1987) Bay K 8644 increases release of acetylcholine at the murine neuromuscular junction. Brain Res 419:315-319.

Augustine GJ, Charlton MP, Smith SJ (1987) Calcium action in synaptic transmitter release. Annu Rev Neurosci 10:633-693.

Barres BA, Chun L.LY, Corey DP (1990) Ion channels in vertebrate glia. Annu Rev Neurosci 13:441-474.

Betz W, Sakmann B (1971) "Disjunction" of frog neuromuscular synapses by treatment with proteolytic enzymes. Nature 232:94-95.

Birks R, Huxley HE, Katz B (1960) The fine structure of the neuromuscular junction of the frog. J Physiol (Lond) 150:134-144.

Bowersox SS, Miljanich GP, Sugiura Y, Li C, Nadasdi L, Hoffman BB, Ramachandran J, Ko C-P (1995) Differential blockade of voltage-sensitive calcium channels at the mouse neuromuscular junction by novel and $\omega$-conopeptides and $\omega$-agotoxin-IVA. J Pharmacol Exp Ther 273:248-256.

Chiu SY (1991) Functions and distribution of voltage-gated sodium and potassium channels in mammalian Schwann cells. Glia 4:541-558.

Chiu SY, Kriegler S (1994) Neurotransmitter-mediated signaling between axons and glial cells. Glia 11:191-200.

Cohen MW, Jones OT, Angelides KL (1991) Distribution of $\mathrm{Ca}^{2+}$ channels on frog motor nerve terminals revealed by fluorescent $\omega$-conotoxin. J Neurosci 11:1032-1039.

Couteaux R, Pécot-Dechavassine M (1974) Les zones spécialisécs des membranes présynaptiques. CR Acad Sci III 278:291-293. 
Cull-Candy SG, Mathie A, Symonds CJ, Wyllie DJA (1989) Distribution of quisqualate and kainate receptors in rat type-2-astrocytes and their progenitor cells in culture. J Physiol (Lond) 478:195.

Dani JW, Chernjavsky A, Smith SJ (1992) Neuronal activity triggers calcium waves in hippocampal astrocyle networks. Neuron 8:429-440.

Derouiche A, Frotscher M (1991) Astroglial processes around identified glutamatergic synapses contain glutamine synthetase: evidence for transmitter degradation. Brain Res 552:346-350.

Dreyer F, Peper K, Akert K, Sandri C, Moor H (1973) Ultrastructure of the "active zone" in the frog neuromuscular junction. Brain Res 62:373-380.

Flucher BE, Morton ME, Froehner SC, Daniels MP (1990) Localization of the $\alpha 1$ and $\alpha 2$ subunits of the dihydropyridine receptor and ankyrin in skeletal muscle triads. Neuron 5:339-351.

Georgiou J, Robitaille R, Trimble WS, Charlton MP (1994) Synaptic regulation of glial protein expression in vivo. Neuron 12:443-455.

Herrera AA, Grinnell AD, Wolowske B (1985) Ultrastructural correlates of naturally occurring differences in transmitter release efficacy in frog motor nerve terminals. J Neurocytol 14:193-202.

Hofmann F, Biel M, Flockerzi V (1994) Molecular basis for $\mathrm{Ca}^{2+}$ channel diversity. Annu Rev Neurosci 17:399-418.

Jahromi BS, Robitaille R, Charlton MP (1992) Transmitter release increases intracellular calcium in perisynaptic Schwann cells in situ. Neuron 8:1069-1077.

Jahromi BS, Robitaille R, Charlton MP (1993) Muscarinic $\mathrm{Ca}^{2+}$ responses unaffected by muscarinic antagonists. Soc Neurosci Abstr 19:463.

Jorgensen AO, Shen AC-Y, Arnold W, Leung AT, Campbell KP (1989) Subcellular distribution of the 1,4-dihydropyridine receptor in rabbit skeletal muscle in situ: an immunofluorescence and immunocolloidal gold-labcled study. J Ccll Biol 109:135-147.

Kao JPY, Harootunian AT, Tsien RY (1989) Photochemically generated cytosolic calcium pulses and their detection by fluo-3. J Biol Chem 264:8179-8184.

Kawagoe R, Mino H, Takeuchi A (1990) Effects of organic Ca antagonist, diltiazem, on neuromuscular transmission. Jpn $\mathbf{J}$ Physiol 40:325-336

Kerr LM, Yoshikami D (1984) A venom peptide with a novel presynaptic blocking action. Nature 308:282-284.

Kirischuk S, Scherer J, Moller T, Verkhratsky A, Kettenmann H (1995) Subcellular heterogeneity of voltage-gated $\mathrm{Ca}^{2+}$ channels in cells of the oligodendrocyte lineage. Glia 13:1-12.

Knaus HG, Moshammer T, Kang HC, Haugland RP, Glossmann $\mathrm{H}$ (1992) A unique fluorescent phenylalkylamine probe for L-type $\mathrm{Ca}^{2+}$ channels. J Biol Chem 267:2179-2189.

Ko C-P (1987) A lectin, peanut agglutinin, as a probe for the extracellular matrix in living neuromuscular junctions. J Neurocytol 16:567-576.

Lindgren CA, Moore JW (1989) Identification of ionic currents at presynaptic nerve endings of the lizard. J Physiol 414:201-222.

Llinàs R, Sugimori M, Hillman DE, Cherksey B (1992) Distribution and functional significance of the P-type, voltage-dependent $\mathrm{Ca}^{2+}$ channels in the mammalian central nervous system. Trends Neurosci 15:351-355.

McLean IW, Nakane PK (1974) Perindate-lysine-paraformaldehyde fixative. A new fixative for immunoelectron microscopy. J Histochem Cytochem 22:1077-1083.

MacVicar BA (1984) Voltage-dependent calcium channels in glial cells. Science 226:1345-1347.

MacVicar BA, Hochman D, Delay MJ, Weiss S (1991) Modulation of intracellular $\mathrm{Ca}^{2+}$ in cultured astrocytes by influx through voltageactivated $\mathrm{Ca}^{2+}$ channels. Glia 4:448-455.

Magrassi L, Purves D, Lichtman JW (1987) Fluorescent probes that stain living nerve terminals. J Neurosci 7:1207-1214.

Martin DL (1992) Synthesis and release of neuroactive substances by glial cells. Glia 5:81-94.

Müller T, Fritschy JM, Grosche J, Mohler H, Kettenmann H (1994) Developmental regulation of voltage-gated $\mathrm{K}^{+}$channel and GABA receptor expression in Bergman glial cells. J Neurosci 14:2503-2514.

Murphy TH, Worley PF, Baraban JM (1991) L-type voltage-sensitive calcium channels mediate synaptic activation of immediate early genes. Neuron 7:625-635.

Newman EA (1986) High potassium conductance in astrocyte endfeet. Science 233:453-454.

Pancrazio JJ, Viglione MP, Kim YI (1989) Effects of Bay K 8644 on spontaneous and evoked transmitter release at the mouse neuromuscular junction. Neuroscience 30:215-221.
Parpura V, Basarsky TA, Liu F, Jeftinija K, Jeftinija S, Haydon PG (1994) Glutamate-mediated astrocyte-neuron signalling. Nature 369:744-747.

Peper K, McMahan UJ (1972) Distribution of acetylcholine receptors in the vicinity of nerve terminals on skeletal muscle of the frog. Proc R Soc Lond (Biol) 181:431-440.

Peper K, Dreyer F, Sandri C, Akert K, Moor H (1974) Structure and ultrastructure of the frog motor endplate. Cell Tissue Res 149:437-455.

Publicover SJ, Duncan CJ (1979) The action of verapamil on the rate of spontaneous release of the frog neuromuscular junction. Eur J Pharmacol 54:119-127.

Ravens U, Schöpper HP (1990) Opposite cardiac actions of the enantiomers of Bay K 8644 at different membrane potentials in guinea-pig papillary muscles. Naunyn Schmiedebergs Arch Pharmacol 341:232-239.

Rawlins FA, Villegas J (1978) Autoradiographic localization of acetylcholine receptors in the Schwann cell membrane of the squid nerve fiber. J Cell Biol 77:371-376.

Reist NE, Smith SJ (1992) Neurally evoked calcium transients in terminal Schwann cells at the neuromuscular junction. Proc Natl Acad Sci USA 86:5178-5182.

Ribera AB, Nastuk WL (1989) The actions of verapamil at the neuromuscular junction. Comp Biochem Physiol 93:137-141.

Ritchie JM (1992) Voltage-gated ion channels in Schwann cells and glia. Trends Neurosci 15:345-351.

Robitaille R, Adler EM, Charlton MP (1990) Strategic location of cal cium channels at transmitter release sites of frog neuromuscular synapses. Neuron 5:773-779.

Robitaille R, Adler EM, Charlton MP (1993a) Calcium channels and calcium-gated potassium channels at the frog neuromuscular junction. J Physiol (Paris) 87:15-24.

Robitaille R, Garcia ML, Kaczorowski GJ, Charlton MP (1993b) Functional colocalization of calcium and calcium-gated potassium channels in control of transmitter release. Neuron 11:645-655.

Robitaille R (1995) Purinergic receptors and their activation by endogenous purines at perisynaptic glial cells of the frog neuromuscular junction. J Neurosci 15:7121-7131.

Smith SJ (1992) Do astrocytes process neural information? Prog Brain Res 94:119-136.

Sontheimer H, Waxman SG (1993) Expression of voltage-activated ion channels by astrocytes and oligodendrocytes in the hippocampal slice. J Neurophysiol 70:1863-1873.

Sugiura Y, Woppmann A, Miljanich GP, Ko C-P (1995) A novel $\omega$-conopeptide for the presynaptic localization of calcium channels at the mammalian neuromuscular junction. J Neurocytol 24:15-27.

Toutant M, Gabrion J, Vandaele S, Peraldi-Roux S, Barhanin J, Bockaert J, Rouot B (1990) Cellular distribution and biochemical characterization of $\mathrm{G}$ proteins in skeletal muscle: comparative location with voltage dependent calcium channels. EMBO J 9:363-369.

Uchitel OD, Protti DA, Sanchez V, Cherksey BD, Sugimori M, Llinàs R (1992) P-type voltage-dependent calcium channel mediates presynaptic calcium influx and transmitter release in mammalian synapses. Proc Natl Acad Sci USA 89:3330-3333.

van Amsterdam FTM, Punt NC, Haas M, van Amsterdam-Magnoni MS, Zaagsma J (1989) Stereoisomers of BAY K 8644 show opposite activities in the normal and ischaemic rat heart. Naunyn Schmiedebergs Arch Pharmacol 339:647-652.

Vandaele S, Fosset M, Galizzi JP, Lazdunski M (1987) Monoclonal antibodies that coimmunoprecipitate the 1,4-dihydropyridine and phenylalkylamine receptors and reveal the $\mathrm{Ca}^{2+}$ channel structure. Biochemistry 26:5-9.

Vandaele SF, Rieger F (1994) Cu-lucalization of 1,4-dihydropyridine receptor $\alpha 2 / \delta$ subunit and N-CAM during early myogenesis in vitro. J Cell Sci 107:1217-1227.

Verkhratsky AN, Trotter J, Kettenmann H (1990) Cultured glial precursor cells from mouse cortex express two types of calcium currents Neurosci Lett 112:194-198.

Wilson GF, Chiu SY (1990) Ion channels in axon and Schwann cell membranes at paranodes of mammalian myelinated fibers with patch clamp. J Neurosci 10:3263-3274.

Witcher DR, De Waard M, Campbell KP (1993) Characterization of the purified $\mathrm{N}$-type $\mathrm{Ca}^{2+}$ channel and the cation sensitivity of $\omega$-conotoxin GVIA binding. Neuropharmacology 32:1127-1139.

Wray D, Porter V (1993) Calcium channel types at the neuromuscular junction. Ann NY Acad Sci 681:356-367. 